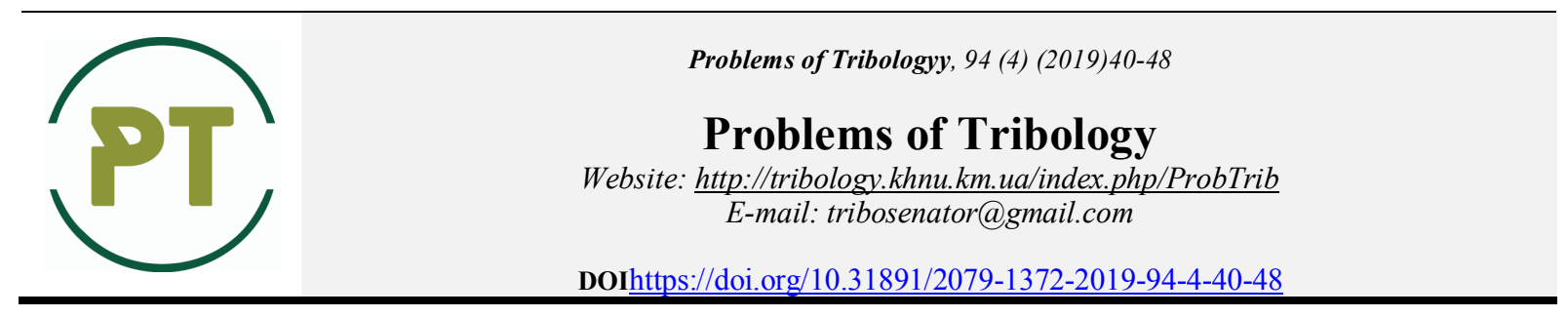

\title{
A flat contact problem the interaction two prestressed stripes with an infinite stringer
}

\author{
N.N. Dikhtyaruk, E.A. Poplavskaya* \\ Khmelnitskyi National University, Ukraine \\ *E-mail: helen.poplavskaya@gmail.com
}

\begin{abstract}
The article is devoted to the research of problems of contact interaction of infinite elastic stringer with two identical clamped along one edge of pre-stressed strips. In general, the research was carried out for the theory of great initial and different variants of the theory of small initial deformations within the framework of linearized theory of elasticity with the elastic potential having arbitrary structure. The integral integer-differential equations are obtained using the integral Fourier transform. Their solution is represented in the form of quasiregular infinite systems of algebraic equations. In the article alsaw was investigated the influence of the initial (residual) stresses in strips on the law of distribution of contact stresses along the line of contact with an infinite stringer. The system is solved in a closed forms using transformation of Fourier. Expressions of stresses are represented by Fourier integrals with a simple enough structure. Influence of initial stress on the distribution of contact stresses is study and discovered the mechanical effects under the influence of concentrated loads.
\end{abstract}

Keywords: linearezed theory of elasticity, initial (residual) stresses, initial deformations, prestressed elastic strip, transformation of Fourier.

\section{Introduction}

The plane contact problem of the transfer of a horizontal concentrated load from an infinite stringer to two identical prestressed strips clamped at one edge is solved using the linearized theory of elasticity. The solution is found in general form for the theory of large initial deformations and different theories of small initial deformations for an arbitrary elastic potential. The problem for the normal and tangential contact stresses is reduced to a system of integro-differential equations derived using the Fourier transforms. The contact stresses are represented by Fourier integrals. It is shown that the initial stresses in the strips affect strongly the distribution of contact stresses: the contact stresses substantially decrease under compression and increase under tension, whereas the displacements increase under compression and decrease under tension. The effect of the initial stresses is stronger in highly elastic materials than in stiff material

\section{Isolation of previously unresolved parts of a common problem}

Contact interaction of initially stressed bodies is one of topical issues in the field of mechanics of deformable solids. The solution to such problems is related to a wide range of questions that arise in engineering, construction and other industries. Strict conditions have been formulated recently: high (guaranteed) durability of structures and machine parts, reliability on the one hand and low material consumption of the latter made with the use of new structural materials. This problem is particularly relevant nowadays and it is of great interest to researchers who solve fundamental and applied problems in the sphere of contact interaction of bodies with initial (residual) stresses. Problems arising up at the transmission of loading from infinite stringers to the elastic stripe - the classic theory of stress, again becomes relevant, in the cases when there are initial (residual) stresses in a stripe. The special necessity of their consideration arises up because of their importance at research of constructions in general and especially in connection with planning of constructions of aircrafts. We will notice that initial (residual) stresses practically always are in the elements of constructions and details of machines and can cause deformations, destructions, increase a tendency to the loss of stability and internal friction, etc. In 
stringent formulation of contact problems for elastic bodies with initial stresses, there is a need to involve the apparatus of nonlinear elasticity theory, which greatly complicates the construction of analytical solutions. But in the case of large (finite) stresses (deformations) it is possible to be limited to consideration the linearized theory of elasticity [1]. In this article, using the relations of the linearized theory of elasticity [2], the solving of the contact problem for the contact interaction of an infinite and finite stringer with a prestressed strip is presented.

\section{Purpose}

The study of the influence of initial (residual) stresses on the law of distribution and displacement under the stringer, along of contact line. Further consideration of the class the contact problems about the contact interaction of elastic stringers with a prestressed strip. Study out the influence of initial (residual) stresses on the law of distribution of contact stresses under reinforcements the elements along line of direct contact as a result of the action on the elastic stringer of concentrated force. In the case of some elastic potentials of the simplest structure to make carry out numerical calculations and construction of graphs.

\section{Presentation of the main material}

Boundary conditions. Contact interaction of an infinite stringer with two prestressed strips. Let the infinite elastic strips made of the same compressible or incompressible materials with the potential of an arbitrary structure. These strips have the same initial (residual) stresses and thicknesses of the strips $-t$. At the edges at $y_{2}= \pm t$, the strips are trapped and under conditions of flat deformation.

We will assume that the infinite elastic strips are connected to each other by an infinite elastic stringer with a modulus of material elasticity $E_{1}$ and the Poisson coefficient $v_{1}$. Let the prestressed strips be loaded with horizontal force $Q_{0} \delta\left(y_{1}\right)$ also, which acting at some midpoint of the stringer. We will use the notation: $\delta\left(y_{1}\right)$ - known single Dirac delta function.

The study of this problem will be carried out in the coordinates of the initial (residual) deformed state $O y_{1} y_{2}$ as shown in the Fig. 1 .

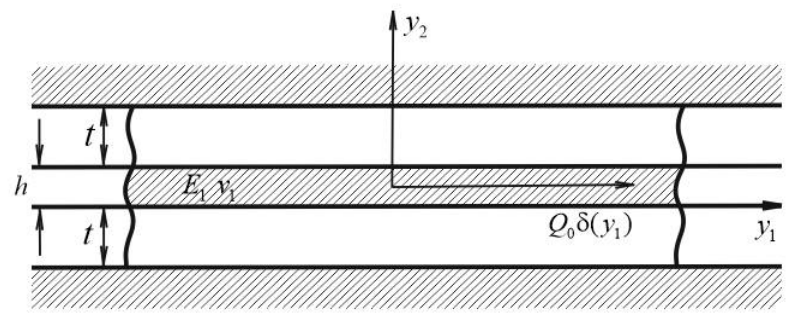

Fig. 1. Effect of force on strips

It is necessary to determine the law of distribution of normal and tangential contact stresses along the line of connection of the stringer with the prestressed stripes. In considering this problem adhering to [2], we believe that the interaction occurs when the known four positions $1-4$ are fulfilled, which are fundamental in the theory of contact interaction of bodies with initial stresses. In addition, we assume that:

1) under the action of applied load and only tangential contact stresses, the stringer is stretched or compressed as a rod in a uniaxial stress state [4];

2) along the horizontal axis, vertical elastic displacements are constant of the due to the small thickness of the stringer.

Denote the intensities of normal and tangential contact stresses $p\left(y_{1}\right)$ and $q\left(y_{1}\right)$, respectively and the vertical and horizontal displacements of the stringer $v^{(1)}\left(y_{1}\right)$ and $u^{(1)}\left(y_{1}\right)$ respectively. Then you can write that:

$$
\begin{gathered}
\frac{\partial u^{(1)}\left(y_{1}\right)}{\partial y_{1}}=\frac{1}{E_{1} h} \int_{-\infty}^{y_{1}}\left[2 q(t)-Q_{0} \delta(t)\right] d t, \quad\left(-\infty<y_{1}<\infty\right) . \\
\frac{\partial v^{(1)}\left(y_{1}\right)}{\partial y_{1}}=0 \quad \forall y_{1} \in\left(-\infty<y_{1}<\infty\right) .
\end{gathered}
$$



tact line:

In case of full contact, it should be noted that the following conditions must be fulfilled along the con-

$$
\frac{\partial v^{(1)}\left(y_{1}\right)}{\partial y_{1}}=\frac{\partial u_{2}^{(2)}\left(y_{1}\right)}{\partial y_{1}} \frac{\partial u^{(1)}\left(y_{1}\right)}{\partial y_{1}}=\frac{\partial u_{1}^{(2)}\left(y_{1}\right)}{\partial y_{1}},\left(-\infty<y_{1}>\infty\right),
$$

where $u^{(1)}\left(y_{1}\right), v^{(1)}\left(y_{1}\right)$ - the components of the displacements vector in the elastic stringer;

$u_{1}^{(2)}\left(y_{1}\right), u_{2}^{(2)}\left(y_{1}\right)$ - the components of the vector of displacements in elastic strips with initial stresses.

\section{The solution method}

We consider the contact conditions (3) together with (1), (2), as well as the expressions for vertical and horizontal displacements of the points free from pinching. The latter were obtained on the basis of the principle of superposition's in the case of equal and unequal roots of the determining equation [2] for compressible and incompressible bodies and following $[3,5]$ have the form:

$$
\begin{aligned}
& u_{1}\left(y_{1}\right)=\int_{-\infty}^{\infty} h_{11}\left(\left|y_{1}-t\right|\right) p(t) d t+\int_{-\infty}^{\infty} h_{12}\left(y_{1}-t\right) q(t) d t, \\
& u_{2}\left(y_{1}\right)=\int_{-\infty}^{\infty} h_{21}\left(y_{1}-t\right) p(t) d t+\int_{-\infty}^{\infty} h_{22}\left(\left|y_{1}-t\right|\right) q(t) d t .
\end{aligned}
$$

Taking into account (1) - (4) relatively unknown contact stresses, we obtain the following system of integro-differential equations:

$$
\begin{gathered}
\frac{d}{d y_{1}}\left[\int_{-\infty}^{\infty} h_{11}\left(\left|y_{1}-t\right|\right) p(t) d t+\int_{-\infty}^{\infty} h_{12}\left(y_{1}-t\right) q(t) d t\right]=0, \\
\frac{d}{d y_{1}}\left[\int_{-\infty}^{\infty} h_{21}\left(y_{1}-t\right) p(t) d t+\int_{-\infty}^{\infty} h_{22}\left(\left|y_{1}-t\right|\right) q(t) d t\right]=\int_{-\infty}^{y_{1}}\left[2 q(t)-Q_{0} \delta(t)\right] d t .
\end{gathered}
$$

where $h_{i j}(i, j=1,2)$ - influence functions for an elastic strip with initial (residual) stresses whose expressions are given [3] and have the form:

- from the action of a unit normal force for the case of equal roots $n_{1}=n_{2}$ :

$$
\begin{aligned}
& h_{11}\left(y_{1}\right)=\frac{1}{\pi} \int_{0}^{\infty} H_{11}(\alpha) \cos \alpha y_{1} d \alpha, \\
& h_{12}\left(y_{1}\right)=\frac{1}{\pi} \int_{0}^{\infty} H_{12}(\alpha) \sin \alpha y_{1} d \alpha ;
\end{aligned}
$$

- for unequal roots $n_{1} \neq n_{2}$ :

$$
\begin{aligned}
& h_{11}\left(y_{1}\right)=\frac{1}{\pi} \int_{0}^{\infty} \tilde{H}_{11}(\alpha) \cos \alpha y_{1} d \alpha, \\
& h_{12}\left(y_{1}\right)=\frac{1}{\pi} \int_{0}^{\infty} \tilde{H}_{12}(\alpha) \sin \alpha y_{1} d \alpha .
\end{aligned}
$$


Here $h_{i j}(\alpha), i, j=1,2-$ is the influence functions characterizing the displacement of the boundary points of the face $y_{2}=0$ of an infinite elastic strip with initial (residual) stresses from the action of a unit normal force. The nuclei $H_{i j}(\alpha)$ respectively have the form:

$$
\begin{aligned}
& \text { - for } n_{1}=n_{2} \\
& H_{11}(\alpha)=H_{1}(\alpha, 0)=n_{0}\left[s_{0} s h^{2} \alpha \varphi_{1}+s_{1} s_{0} s h^{2} \alpha \varphi_{1}-\alpha \varphi_{1} \xi(\alpha)+\left(\alpha \varphi_{1}\right)^{2}-\bar{s}_{1} \xi(\alpha)+\varphi_{1}\right] \cdot \Delta_{1}^{-1}(\alpha) \\
& H_{12}(\alpha)=H_{2}(\alpha, 0)=i \frac{m_{1} n_{0}}{\sqrt{n_{1}}}\left[s_{0} s \xi(\alpha)-s_{0}\left(\alpha \varphi_{1}\right)-\bar{s}_{1} s_{1} \xi(\alpha)+s_{1}\left(\alpha \varphi_{1}\right)\right] \cdot \Delta_{1}^{-1}(\alpha) \\
& \text { - for } n_{1} \neq n_{2}: \\
& \begin{array}{r}
H_{11}(\alpha)=\tilde{H}_{1}(\alpha, 0)=n_{0}\left[-s_{1} c h 2 \alpha \varphi_{1}+s_{0} \xi_{1}(\alpha)-s_{1} s_{0}\left(\alpha \varphi_{1}\right) \xi_{1}(\alpha)+s_{0}\left(\alpha \varphi_{1}\right)^{2} s h^{2} \alpha \varphi_{1}-\right. \\
\left.\quad-s_{0} c h^{2} \alpha \varphi_{1}+s_{1} \xi_{1}(\alpha)+\alpha \varphi_{1} \xi_{4}(\alpha)\right] \cdot \Delta_{2}^{-1}(\alpha) \\
\quad H_{12}(\alpha)=\tilde{H}_{2}(\alpha, 0)=i \frac{n_{0} m_{1}}{\sqrt{n_{1}} \times} \\
\quad \times\left[s_{0} s_{1} \xi_{3}(\alpha)-s_{0}\left(\alpha \varphi_{1}\right) \xi_{1}(\alpha)+s_{1}\left(\alpha \varphi_{1}\right) \xi(\alpha)-s_{1} \xi_{1}(\alpha)\right] \cdot \Delta_{2}^{-1}(\alpha) .
\end{array}
\end{aligned}
$$

Write down the influence functions for an elastic strip with initial (residual) stresses from the action of a unit tangential force:

- for the case of equal roots $n_{1}=n_{2}$ :

$$
\begin{aligned}
& h_{21}\left(y_{1}\right)=\frac{1}{\pi} \int_{0}^{\infty} H_{21}(\alpha) \sin (\alpha) y_{1} d \alpha, \\
& h_{22}\left(y_{1}\right)=\frac{1}{\pi} \int_{0}^{\infty} H_{22}(\alpha) \cos \alpha y_{1} d \alpha .
\end{aligned}
$$

- for unequal roots $n_{1} \neq n_{2}$ :

$$
\begin{aligned}
& h_{21}\left(y_{1}\right)=\frac{1}{\pi} \int_{0}^{\infty} \tilde{H}_{21}(\alpha) \sin (\alpha) y_{1} d \alpha, \\
& h_{22}\left(y_{1}\right)=\frac{1}{\pi} \int_{0}^{\infty} \tilde{H}_{22}(\alpha) \cos \alpha y_{1} d \alpha .
\end{aligned}
$$

The nucleus $H_{i j}(\alpha)$ and $\tilde{H}_{i j}(\alpha)$ respectively have the form:

- for $n_{1}=n_{2}$ :

$$
\begin{gathered}
H_{21}(\alpha)=m_{0}\left[-(s+1)\left(s_{1} \xi(\alpha)-\alpha \varphi_{1}\right)+c h^{2} \alpha \varphi_{1}-s_{1} s h^{2} \alpha \varphi_{1}-s\right]= \\
=m_{0}\left[-(s+1)\left(s_{1} s h \alpha \varphi_{1} c h \alpha \varphi_{1}-\alpha \varphi_{1}\right)+c h^{2} \alpha \varphi_{1}-s_{1} s h^{2} \alpha \varphi_{1}-s\right] \cdot \Delta_{1}^{-1}(\alpha), \\
H_{22}(\alpha)=i \frac{m_{0} m_{1}}{\sqrt{n_{1}}}\left[s \cdot s_{1} \operatorname{ch}^{2} \alpha \varphi_{1}+\left(\alpha \varphi_{1}\right)^{2}-\alpha \varphi_{1} \xi(\alpha)-s_{1}^{2} s^{2}\left(\alpha \varphi_{1}\right)-s \cdot s_{1}\right] \cdot \Delta_{1}^{-1}(\alpha) ;
\end{gathered}
$$


- for $n_{1} \neq n_{2}$ :

$$
\begin{gathered}
\tilde{H}_{21}(\alpha)=m_{0}\left[-s s_{1}\left(\alpha \varphi_{1}\right) \xi_{2}(\alpha)-s \xi_{3}(\alpha)+s\left(\alpha \varphi_{1}\right) \xi_{2}(\alpha)+\xi_{3}(\alpha)\right] \cdot \Delta_{2}^{-1}(\alpha), \\
\tilde{H}_{22}(\alpha)=i \frac{m_{0} m_{1}}{\sqrt{n_{1}}}\left[1-s_{1} \operatorname{ch}\left(2 \alpha \varphi_{2}\right)+s s_{1} \xi_{1}(\alpha)+s \alpha \varphi_{1} \xi_{4}(\alpha)+s s_{1}\left(\alpha \varphi_{1}\right)^{2} s h^{2} \alpha \varphi_{1}-\right. \\
\left.\quad-s s_{1} \operatorname{ch}^{2} \alpha \varphi_{21}-s_{1}^{2}\left(\alpha \varphi_{1}\right) \xi_{4}(\alpha)+\xi_{3}(\alpha)\right] \cdot \Delta_{2}^{-1}(\alpha) .
\end{gathered}
$$

We also note that, the following asymptotic formulas hold:

at the $\alpha \rightarrow 0$ :

$$
H_{11}(\alpha)=\tilde{H}_{11}(\alpha)=0(1) ; \quad H_{12}(\alpha)=\tilde{H}_{12}(\alpha)=0(\alpha) ; H_{22}(\alpha)=\tilde{H}_{22}(\alpha)=0(1) ;
$$

at the $\alpha \rightarrow \infty$ :

$$
H_{11}(\alpha)=\tilde{H}_{11}(\alpha)=0\left(\frac{1}{\alpha}\right) ; \quad H_{12}(\alpha)=\tilde{H}_{12}(\alpha)=0\left(\frac{1}{\alpha}\right) ; \quad H_{22}=\tilde{H}_{22}(\alpha)=0\left(\frac{1}{\alpha}\right) .
$$

Multiply the first and second equations (5) by $e^{-i \alpha y_{1}}$ and integrate them by $y_{1}$ from $-\infty$ to $+\infty$. Applying the convolution theorem after elementary calculations, we obtain a system of algebraic equations with respective Fourier transforms $\tilde{p}(\alpha)$ and $\tilde{q}(\alpha)$ :

$$
\begin{gathered}
H_{11}(\alpha) \tilde{p}(\alpha)-i H_{12}(\alpha) \tilde{q}(\alpha)=0, \\
E_{1} t_{0} \alpha^{2} i H_{21}(\alpha)-\left[E_{1} t_{0} \alpha^{2} H_{22}(\alpha)+2\right] \tilde{q}(\alpha)=Q_{0} .
\end{gathered}
$$

Here we introduce the following notation:

$$
\tilde{p}(\alpha)=\int_{-\infty}^{\infty} p\left(y_{1}\right) e^{i \alpha y_{1}} d y_{1}, \quad \tilde{q}(\alpha)=\int_{-\infty}^{\infty} q\left(y_{1}\right) e^{i \alpha y_{1}} d y_{1} .
$$

The functions $\tilde{p}(\alpha), \tilde{q}(\alpha)$ - the essence of Fourier transforms from function $p\left(y_{1}\right), q\left(y_{1}\right)$ - are the contact voltages on the contact line of the elastic stringer and the strips with initial (residual) stresses; $Q_{0}$ - the external horizontal load; the functions $H_{i j}(i=1,2)$ for the equal and unequal roots of the determining equation [2] are given by formulas (12) (13), respectively.

To find the Fourier transforms $\tilde{p}(\alpha)$ and $\tilde{q}(\alpha)$ we write down the determinants of the system (15):

$$
\begin{gathered}
H^{*}(\alpha)=\left|\begin{array}{cc}
H_{11}(\alpha) & -i H_{12}(\alpha) \\
0 & E_{1} t_{0} \alpha^{2} H_{22}(\alpha)+2
\end{array}\right|=H_{11}(\alpha)\left[E_{1} t_{0} \alpha^{2} H_{22}(\alpha)+2\right]=H_{11}^{*}(\alpha) H_{22}^{*}(\alpha) . \\
\Delta_{1}^{*}(\alpha)=\left|\begin{array}{cc}
0 & -H_{12}(\alpha) \cdot i \\
E_{1} t_{0} \alpha^{2} i H_{21}(\alpha)-Q_{0} & E_{1} t_{0} \alpha^{2} H_{22}(\alpha)+2
\end{array}\right|=H_{21}^{*}(\alpha) \cdot H_{12}^{*}(\alpha), \\
\Delta_{2}^{*}(\alpha)=\left|\begin{array}{cc}
H_{11}(\alpha) & 0 \\
0 & E_{1} t_{0} \alpha^{2} i H_{21}(\alpha)-Q_{0}
\end{array}\right|=H_{11}^{*}(\alpha) H_{21}^{*}(\alpha) .
\end{gathered}
$$


Here we introduce the following notation:

$$
\begin{aligned}
& H_{11}^{*}(\alpha)=H_{11}(\alpha), H_{12}^{*}(\alpha)=-i H_{12}(\alpha), H_{21}^{*}(\alpha)= \\
& =E_{1} t_{0} \alpha^{2} i H_{21}(\alpha)-Q_{0}, H_{22}^{*}(\alpha)=E_{1} t_{0} \alpha^{2} H_{22}(\alpha)+2 .
\end{aligned}
$$

Applying the Kramer formulas and the inverse Fourier transform, we obtain the solution of the system of integer-differential equations (5). This solution gives the expressions for the required contact voltages in the form:

$$
\begin{aligned}
& q\left(y_{1}\right)=\frac{Q_{0}}{\pi} \mu \int_{0}^{\infty} \frac{H_{11}^{*}(\alpha)}{H^{*}(\alpha)} \cos \alpha y_{1} d \alpha, \\
& p\left(y_{1}\right)=\frac{Q_{0}}{\pi} \mu \int_{0}^{\infty} \frac{H_{11}^{*}(\alpha)}{H^{*}(\alpha)} \sin \alpha y_{1} d \alpha .
\end{aligned}
$$

Here, the values $H_{i}^{*}$ and $H_{i j}^{*}(i, j=1,2)$ are expressed by known functions $H_{i j}(i, j=1,2)$, which are determined according to formulas (12) - (13) for equal and unequal roots of the determining equation [2] in the case of a particular structure of elastic potentials.

Let us investigate the convergence of improper integrals of the formulas (20). Taking into account the value $H_{i j}^{*}(\alpha)$ (19) and values $H_{i j}(\alpha)$ (12) - (13), and well as asymptotic formulas for $H_{i j}(\alpha)$ omitting the cumbersome elementary transformations, we find the following asymptotic expressions:

$$
\begin{array}{ll}
\text { at } \alpha \rightarrow 0 & \frac{H_{12}^{*}(\alpha)}{H^{*}(\alpha)} \sim 0(\alpha) . \\
\text { at } \alpha \rightarrow \infty & \frac{H_{12}^{*}(\alpha)}{H^{*}(\alpha)} \sim 0\left(\alpha^{-1}\right) .
\end{array}
$$

It follows from the asymptotes (21) - (22) that in (20) the second integral expressing the law of distribution of normal contact stresses converges rather quickly.

As for the first integral $\int_{0}^{\infty} \frac{H_{11}^{*}(\alpha)}{H^{*}(\alpha)} \cos \alpha y_{1} d \alpha$, which expresses the law of distribution of tangential contact stresses, its convergence can be accelerated, by presenting $\frac{H_{11}^{*}(\alpha)}{H^{*}(\alpha)}$ in the form:

$$
\frac{H_{11}^{*}}{H^{*}(\alpha)} \approx \frac{C_{2}}{c_{2}+\alpha}+0\left(\ell^{-2 t \alpha}\right), \quad(t>0) \quad \text { at the } \alpha \rightarrow \infty
$$

Here, the $C_{2}$ and $c_{2}$ - constants that significantly depend on the roots of the determining equation [2], the particular shape of the elastic potential and are determined from formulas (8) and (9) for the specific compressible and incompressible construction materials. From the continuity of contact tangential stresses, considering the thickness of the elastic plates $h$ and the elastic constants of the material $\lambda$ and $\mu$ from which the elastic plates is made.

The constant $C_{2}$ can be represented as:

$$
C_{2}=\frac{2 c+1}{E_{1} t_{0}(c+1)}, \quad c=\frac{\lambda+\mu}{2 \mu} \quad\left(c_{2}=2 \mu C_{2}\right)
$$


Taking into account (23) and (24) we get the following:

$$
\begin{gathered}
\int_{0}^{\infty} \frac{H_{11}^{*}(\alpha)}{H^{*}(\alpha)} \cos \alpha y_{1} d \alpha=-C_{2}\left(\cos c_{2} y_{1} c i c_{2} y_{1}+\sin c_{2} y_{1} s i c_{2} y_{1}+\right. \\
+\int_{0}^{\infty}\left[\frac{\left(c_{2}+\alpha\right) H_{11}^{*}(\alpha)-C_{2} H^{*}(\alpha)}{\left(c_{2}+\alpha\right) H^{*}(\alpha)}\right] \cos \alpha y_{1} d \alpha .
\end{gathered}
$$

Where $\operatorname{si}\left(c_{2} y_{1}\right)=-\int_{c_{2} y_{1}}^{\infty} \frac{\sin \alpha}{\alpha} d \alpha, c i\left(c_{2} y_{1}\right)=-\int_{c_{2} y_{1}}^{\infty} \frac{\cos \alpha}{\alpha} d \alpha-$ the sine and cosine integrals.

The last integral in (25) with considering (23) converges rather quickly since:

$$
\frac{\left(c_{2}+\alpha\right) H_{11}^{*}(\alpha)-C_{2} H^{*}(\alpha)}{\left(c_{2}+\alpha\right) H^{*}(\alpha)} \sim 0(\alpha), \text { at the } \alpha \rightarrow 0
$$

Therefore considering (25) for the contact tangential stresses (20) from the action of horizontal external force $Q_{0} \delta\left(y_{1}\right)$, we get the following:

$$
\begin{gathered}
q\left(y_{1}\right)=-\frac{Q_{0}}{2 \pi} \times \\
\times\left[c_{2}\left(\cos c_{2} y_{1} c i\left(c_{2} y_{1}\right)+\sin c_{2} y_{1} \operatorname{si}\left(c_{2} y_{1}\right)\right)-\int_{0}^{\infty} \frac{2 \mu\left(c_{2}+\alpha\right) H_{11}^{*}(\alpha)-c_{2} H^{*}(\alpha)}{\left(c_{2}+\alpha\right) H^{*}(\alpha)} \cos \alpha y_{1} d \alpha\right] \\
\left(-\infty<y_{1}>\infty\right)
\end{gathered}
$$

\section{Analysis of numerical results and investigation results}

In the last formula, the first number with the precision of a constant is Melan's well-known solution [4]. On the basis of formula (27) a numerical analysis $[3,5,6]$ was performed, the results of which are presented in graphs (Fig. 2, 3). All numerical results and graphs are obtained in Maple -8, for the harmonic potential, the potential of Bartenev-Khazanovich, in the case of equal roots of the defining equation [2]. The graphs (Fig. 2, 3) illustrate the effect of the initial (residual) stresses in the elastic stripes on the law of contact stresses distribution under the stringer from the action of tangential force $Q_{0} \delta\left(y_{1}\right)$ for the dimensionless values $\frac{h}{Q} q(t)$.

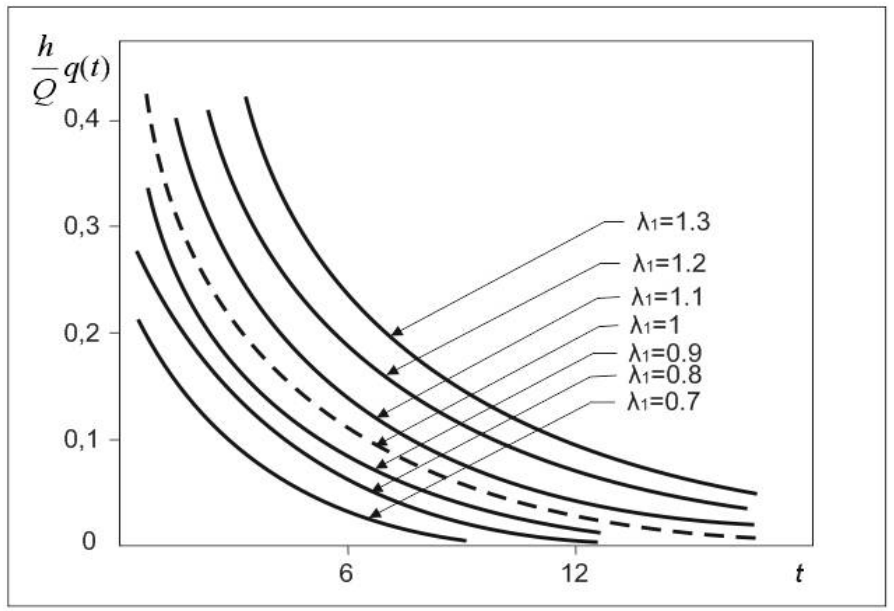

Fig. 2. Distribution of contact stresses for harmonic potential 


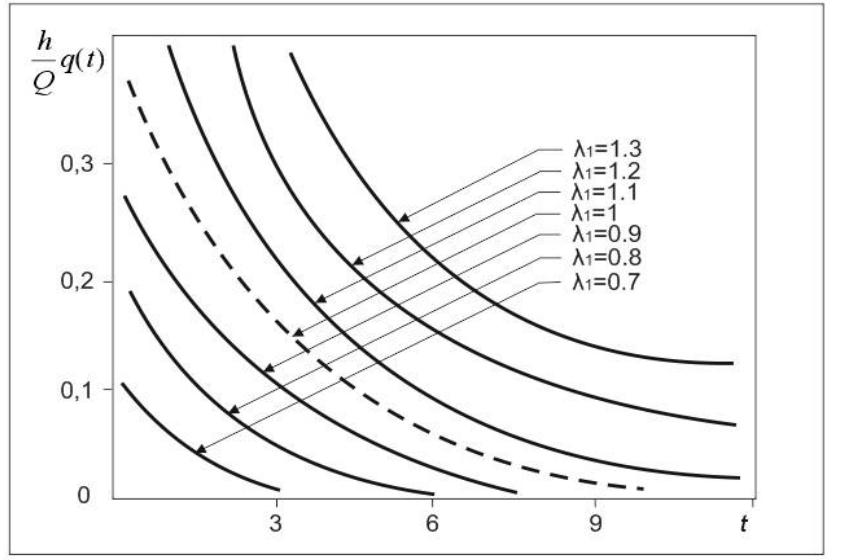

Fig. 3. Distribution of contact stresses for potential Bartenev-Khazanovich

Here $\frac{h}{Q} q(t)-$ are dimensionless contact tangential stresses. The values $\lambda_{1}=1$ (dotted line in Fig. 2, 4) - correspond to the classical theory of elasticity and coincides with the results of paper [7]; $\lambda_{1}=0,7 ; 0,8 ; 0,9$ - correspond to the initial stresses of compression; $\lambda_{1}=1,1 ; 1,2 ; 1,3$ - correspond to the initial tensile stress; $t$ - the dimensionless coordinate of the initial stressed state in the elastic stripes with the initial stresses.

\section{Conclusions}

The got results undertaken a study give an opportunity to do the row of summarizing conclusions, that to influence of initial tensions on the law of distribution of pin efforts under an endless protective strap that cooperates with one and with two preliminary tense stripes.

1. In general case at the event and unequal roots of qualificatory equalization [2] for this type of tasks that examined within the framework of the linearized theory of resiliency, the general method of their uniting, that gives an opportunity to get the upshots of the put tasks if the known decision of analogical linear (without initial tensions) tasks, is set forth.

2. In case of even chums of qualificatory equalization [2] for bodies with resilient potentials of free-form of tension and moving to the ends of resilient protective straps have a feature that fully coincides with a feature in the analogical tasks of classic linear theory of resiliency. In case of unequal chums, leading to the identity of order of the indicated features is not succeeded.

3. The analysis of numerical results shows that in case of clench the presence of initial tensions in a resilient stripe results in considerable reduction of pin tensions, in case of elongation - to their increase. And from the illustrated charts (Fig. 2,3) follows, that more substantial influence of initial tensions is observed in highly elastic materials.

\section{References}

1. Гузь А.Н. Контактное взаимодействие упругих тел с начальными (остаточными) напряжениями / А.Н. Гузь, С.Ю. Бабич, В.Б. Рудницкий // Развитие идей Л. А. Галина в механике. К столетию со дня рождения ученого. - М. ; Ижевск : Ин-т комп’ютер. исслед., 2013. - С. 188-244.

2. Гузь А.Н. Основы теории контактного взаимодействия упругих тел с начальными (остаточными) напряжениями [Текст] / А.Н. Гузь, В.Б. Рудницкий. - Хмельницкий: Изд-во “ПП Мельник”, 2006. $710 \mathrm{c}$.

3. Дихтярук Н.Н. О равновесии полосы с начальными напряжениями, усиленной упругими накладками / Н.Н. Дихтярук // Прикл. механика. - 2004, - 40, № 3 - С. 63 - 70.

4. Діхтярук М. М. Передача навантаження від нескінченного стрингера до двох затиснених по одному краю однакових смуг з початковими (залишковими) напруженнями / М. М. Діхтярук // Вісник ТНТУ. $-2016,-83$, № 3, -С. 51-60. 128 (1932).

5. E. Melan, "Ein Beitrag zur Theorie geschweiss der Verbindungen," Ingenieur Archiv, 3, No. 2, 126

6. Рудницкий, В. Б., Дихтярук Н.Н. Упругая полоса с начальными напряжениями, усиленная упругими накладками./ В. Б. Рудницкий, Н.Н. Дихтярук Н.Н. // Прикл. механика., 2002, - 38, № 11. C. $81-88$. 
7. Рудницкий, В. Б., Дихтярук Н.Н. Контактная задача о взаимодействии бесконечного стрингера и двух одинаковых полос с начальными напряжениями. / В. Б. Рудницкий, Н.Н. Дихтярук Н.Н. // Прикл. механика, 2017, - 53, № 2, - С. $41-48$.

8. Dikhtyaruk, N.N. Equilibrium of a prestressed strip reinforced with elastic plates // International Applied Mechanics. - March 2004, Volume 40, Issue 3, pp 290-296.

9. Rudnitskii V.B., Dikhtyaruk N.N. A prestressed elastic strip with elastic reinforcements / V.B. Rudnitskii, N.N. Dikhtyaruk// International Applied Mechanics. - November 2002, Volume 38, Issue 11, pp 13541360 .

10. Rudnitskii V.B. , Dikhtyaruk N.N. Interaction Between an Infinite Stringer and Two Identical Prestressed Strips: Contact Problem /, V.B. Rudnitskii, N.N Dikhtyaruk // Translated from Prikladnaya Mekhanika, Vol. 53, No. 2, pp. 41-48, March-April, 2017.

11. Діхтярук М.М. Аналог задачі Мелана для пружної смуги з початковими напруженнями підсиленною пружною накладкою [Текст] / М. М. Діхтярук, О. А. Поплавська // Проблеми трибології. 2018. - №1. - C. 37-42.

Діхтярук М.М., Поплавська О.А. Плоска контактна задача про взаємодію двох попередньо напружених смуг з нескінченним стрингером

Робота присвячена проблемам контактної взаємодії нескінченного пружного стрингера 3 двома попередньо напруженими смугами. Дослідження проводилося в рамках лінеаризованої теорії пружності у загальній формі для теорії великих (кінцевих) початкових деформацій та двох варіантів теорії малих початкових деформацій 3 довільною структурою пружного потенціалу. Базуючись на припущенні, що стрингери завантажують одночасно вертикальні та горизонтальні сили, справедлива модель згину балки в поєднанні з горизонтальним розтягом стрижня. Ця проблема сформульована математично як система інтегро-диференціальних рівнянь відносно невідомого контактних напружень. Використовуючи перетворення Фур'є, система розв'язується у замкнутому вигляді. Вирази напружень представлені інтегралами Фур'є досить простою структурою. Досліджено вплив початкових напружень на розподіл контактних напружень та виявлені механічні ефекти під дією зконцентрованих навантажень.

Ключові слова: лінеаризована теорія пружності, початкові (залишкові ) напруження, контактні задачі, інтегральні перетворення Фур'є. 